\title{
Analisis Kemampuan Pemahaman Konsep Matematis Peserta Didik pada Materi Bangun Ruang Sisi Datar Ditinjau dari Gender
}

\author{
Mukhlisatul Humaira Syaifar ${ }^{1}$, Maimunah ${ }^{2}$, Yenita Roza ${ }^{3}$ \\ 1, 2,3 Program Studi Magister Pendidikan Matematika, Universitas Riau \\ Jalan Kampus Bina Widya KM 12.5, Pekanbaru, Riau, Indonesia \\ humairasyaifar123@gmail.com
}

\begin{abstract}
This study aims to describe the ability to understand students' mathematical concepts in terms of gender. The ability to understand mathematical concepts is analyzed from problem solving. The research method applied is descriptive qualitative. The research subjects were students of class IX of SMPN 1 Pekanbaru, which consisted of 12 girls and 12 boys. The research instrument used was a concept understanding ability test sheet consisting of five valid description questions. Data were collected through tests. The data is analyzed based on indicators of the ability to understand mathematical concepts, namely restating the concepts that have been studied, identifying examples and non-examples of a concept, presenting concepts in the form of mathematical representations, using certain procedures or operations, and applying concepts algorithmically in problem solving. Data were compared by gender. The results showed that the ability to understand mathematical concepts of female students was better than male students on the indicators of restating the concepts that had been studied, identifying examples and not examples of a concept, presenting concepts in the form of mathematical representations, using certain procedures or operations and apply concepts algorithmically in problem solving.
\end{abstract}

Keywords: Gender, Understanding of Mathematical Concepts Ability, Three Dimensional Figures

\begin{abstract}
Abstrak
Peserta didik laki-laki berbeda dengan perempuan dalam memperoleh, memahami serta menguasai konsep matematika. Penelitian ini bermaksud untuk menggambarkan kemampuan pemahaman konsep matematis peserta didik ditinjau dari gender. Kemampuan pemahaman konsep matematis dianalisis dari penyelesaian soal. Penelitian ini menerapkan metode deskriptif kualitatif. Subjek penelitian adalah peserta didik laki-laki dan perempuan kelas IX SMPN 1 Pekanbaru, masing-masing sebanyak 12 orang. Instrumen penelitian yang digunakan berupa tes tertulis kemampuan pemahaman konsep yang terdiri dari lima soal uraian yang telah valid dan wawancara. Data dianalis berdasarakan indikator kemampuan pemahaman konsep matematis yaitu menyatakan ulang konsep yang telah dipelajari, mengidentifikasi contoh dan bukan contoh dari suatu konsep, menyajikan konsep dalam bentuk representasi matematis, menggunakan prosedur atau operasi tertentu serta mengaplikasikan konsep secara algoritma dalam pemecahan masalah. Data dibandingkan berdasarkan gender. Hasil penelitian menunjukkan bahwa kemampuan pemahaman konsep matematis peserta didik perempuan lebih baik daripada laki-laki pada indikator menyatakan ulang konsep yang telah dipelajari, mengidentifikasi contoh dan bukan contoh dari suatu konsep, menyajikan konsep dalam bentuk representasi matematis, menggunakan prosedur atau operasi tertentu serta mengaplikasikan konsep secara algoritma dalam pemecahan masalah.
\end{abstract}

Kata kunci: Gender, Kemampuan Pemahaman Konsep Matematis, Bangun Ruang Sisi Datar

Copyright (c) 2022 Mukhlisatul Humaira Syaifar, Maimunah, Yenita Roza

$\triangle$ Corresponding author: Maimunah

Email Address: maimunah@lecturer.unri.ac.id (Jalan Kampus Bina Widya KM 12.5, Pekanbaru, Riau)

Received 01 November 2021, Accepted 24 January 2022, Published 27 January 2022

\section{PENDAHULUAN}

Pembelajaran matematika dapat mengasah dan mengembangkan berbagai kemampuan berifikir. Matematika tersusun dari konsep-konsep yang terstruktur, dari konsep yang sederhana hingga yang kompleks, sistematis dan saling terkait (Khasanah et al., 2020). Tujuan pembelajaran matematika agar peserta didik menguasai konsep yang telah dipelajari; menggunakan pola sebagai hipotesis menyelesaikan masalah; memanipulasi matematika dalam menyelesaikan masalah di dalam maupun 
di luar matematika (Permendikbud No 58 Tahun 2014). Memahami suatu konsep adalah kunci dalam menggapai tujuan pembelajaran. Pemahaman konsep matematis menentukan keberhasilan peserta didik mempelajari matematika (Hernaeny et al., 2021). Hendriana et al (2017) menyatakan bahwa suatu kompentensi dasar mempelajari matematika mencakup kemampuan memahami suatu materi, mengingat kembali rumus dan mengaplikasikannya dalam persoalan yang mirip, memprediksi kesesuaian suatu pernyataan, menyelesaikan masalah dengan menerapkan rumus serta teorema disebut kemampuan pemahaman konsep matematis.

Pada dasarnya, kemampuan pemahaman konsep menjadi landasan untuk mempelajari matematika sehingga peserta didik bukan sekedar mengetahui materi namun menjadikan pembelajaran yang bermakna (Yulianty, 2019). Pemahaman konsep matematika wajib dikuasai terlebih dahulu sehingga peserta didik paham terhadap konsep berikutnya serta menerapkan konsep untuk memecahkan persoalan matematika yang ada di lingkungan sekitar. Kemampuan pemahaman konsep merupakan pondasi dalam mengembangkan kemampuan koneksi, komunikasi, representasi, argumentasi, pemecahan masalah, berfikir kritis dan kreatif matematis (Mulyani et al., 2018). Jika tidak memahami suatu konsep matematika, maka akan kesulitan menghubungkan ide-ide untuk menyelesaikan suatu permasalahan karena pengetahuan yang dimiliki sangat terbatas (Halimatusadiah, 2017). Berdasarkan uraian sebelumnya, kemampuan pemahaman konsep matematis sangat penting dikuasai peserta didik.

Kemampuan peserta didik SMP untuk memahami suatu konsep matematis rendah. Pernyataan tersebut didukung oleh hasil penelitian Handayani \& Aini (2019) bahwa persentase kemampuan peserta didik dalam memahami konsep peluang yaitu 31,25\% dengan kriteria rendah. Peserta didik tidak dapat menentukan Iangkah-langkah penyeIesaian soaI konsep peluang. (Hernaeny et al., 2021) menyatakan bahwa rendahnya kemampuan peserta didik SMP dalam memahami konsep bangun ruang sisi datar disebabkan oleh ketidakmampuan dalam mengidentifikasi konsep serta tidak tepat dalam penggunaan rumus. Sejalan dengan hasil penelitian tersebut, Mulyani et al., (2018) menyatakan bahwa peserta didik kesulitan menyelesaikan soal karena tidak dapat mengaplikasikan rumus dengan tepat, tidak dapat mengaitkan dan menerapkan konsep materi bentuk aljabar. Yani et al., (2019) menyatakan bahwa dalam menyelesaikan soal pemahaman konsep matematis pada materi bangun ruang sisi lengkung, peserta didik kesulitan dalam memberikan contoh dan bukan contoh dari konsep. Peserta didik juga tidak memahami konsep dan hanya menghapal rumusnya saja sehingga kesulitan dalam mengaitkan berbagai konsep. Terdapat faktor yang memengaruhi pemahaman konsep matematis seperti kesiapan peserta didik belajar, self-efficacy, minat, gaya belajar, gender dan sebagainya (Khasanah et al., 2020).

Beberapa penelitian sebelumnya mendiskusikan mengenai gender. Laki-laki berbeda dengan perempuan ketika memperoleh, memahami serta menguasai konsep matematika (MZ, 2013). Ketelitian dan ketepatan peserta didik perempuan lebih baik daripada laki-laki namun tidak lebih baik dalam bernalar (Nafi'an, 2011). Peserta didik laki-laki tepat dalam mengambil simpulan dari suatu 
pernyataan serta menerapkan logika dalam menyelesaikan permasalahan dibandingkan dengan peserta didik perempuan Susilowati (2016), Penelitian et al., (2021) dan Achor, (2010) menyatakan bahwa prestasi dan kemampuan peserta didik perempuan saat berkomunikasi unggul daripada laki-laki. Sedangkan Khasanah et al., (2020) menyatakan bahwa kemampuan menyatakan ulang konsep peserta didik laki-laki terstruktur daripada perempuan dan unggul dalam pembelajaran geometri. Kemampuan spasial peserta didik perempuan tidak sebaik laki-laki namun kemampuan verbalnya lebih bagus (Bayar, 2018). Berdasarkan pernyataan penelitian sebelumnya, kemampuan peserta didik setiap individu berbeda-beda dan gender menjadi salah satu faktor yang memengaruhinya. Sesuai dengan pernyataan Kurniasi, (2016) bahwa perbedaan gender memengaruhi pemahaman konsep peserta didik.

Pemahaman konsep dalam geometri meningkatkan keterampilan peserta didik dalam mencari solusi permasalahan kehidupan sehari-hari (Abdussakir, 2012). Salah satu ruang lingkup dari geometri adalah bangun ruang sisi datar. Badraeni et al., (2020) menyatakan bahwa dalam menyelesaikan soal bangun ruang sisi datar, peserta didik kesulitan dalam mengaitkan satu konsep atau prinsip dengan konsep atau prinsip lainnya. Rumus yang digunakan peserta didik dalam perhitungan sederhana maupun perhitungan secara instrumental tidak tepat. Perlu adanya analisis kemampuan peserta didik dalam memahami konsep materi bangun ruang sisi datar yang ditinjau berdasarkan gender. Berdasarkan uraian tersebut, peneliti tertarik dalam menganalisis kemampuan pemahaman konsep matematis pada materi bangun ruang sisi datar yang ditinjau dari gender.

\section{METODE}

Penelitian ini termasuk penelitian deskriptif kualitatif yang mendeskripsikan kemampuan pemahaman konsep matematis peserta didik dalam menyelesaikan soal ditinjau dari gender. Subjek penelitian adalah peserta didik kelas IX Dang Merdu SMPN 1 Pekanbaru pada semester ganjil tahun ajaran 2021/2022 sebanyak 24 orang meliputi 12 peserta didik perempuan dan 12 peserta didik lakilaki yang berkemampuan beragam dan telah mempelajari materi bangun ruang sisi datar. Data penelitian dikumpulkan melalui tes dan wawancara. Instrumen tes yang digunakan yaitu lembar tes kemampuan pemahaman konsep yang terdiri dari lima soal uraian yang telah valid. Setiap soal memuat satu indikator kemampuan pemahaman konsep matematis yang berbeda. Setiap indikator soal, dipilih 1 peserta didik laki-laki dan perempuan untuk diwawancarai guna mengetahui penyebab peserta didik salah menyelesaikan soal. Hasil tes peserta didik dinilai berdasarkan rubrik penskoran yang dimodifikasi dari Kasum (dalam Kartika, 2018) untuk menunjukkan kemampuan pemahaman konsep matematis pada materi bangun ruang sisi datar.

Data penelitian dianalisis per indikator kemampuan pemahaman konsep matematis. Indikator kemampuan konsep matematis pada penelitian ini yaitu menyatakan ulang konsep yang telah dipelajari, mengidentifikasi contoh dan bukan contoh dari suatu konsep, menyajikan konsep dalam bentuk representasi matematis, menggunakan prosedur atau operasi tertentu, dan mengaplikasikan konsep secara algoritma dalam pemecahan masalah. Data dibandingkan berdasarkan gender. Rubrik 
penskoran kemampuan pemahaman konsep matematis disajikan dalam tabel 1.

Tabel 1. Rubrik Penskoran Kemampuan Pemahaman Konsep Matematis

\begin{tabular}{|c|c|c|}
\hline $\begin{array}{l}\text { Indikator Pemahaman } \\
\text { Konsep }\end{array}$ & Keterangan & Skor \\
\hline \multirow{3}{*}{$\begin{array}{l}\text { Menyatakan ulang } \\
\text { konsep yang telah } \\
\text { dipelajari }\end{array}$} & Tidak dapat menyatakan ulang konsep & 1 \\
\hline & Dapat menyatakan ulang konsep tetapi belum lengkap & 2 \\
\hline & Dapat menyatakan ulang konsep dengan tepat dan lengkap & 3 \\
\hline \multirow{4}{*}{$\begin{array}{l}\text { Mengidentifikasi contoh } \\
\text { dan bukan contoh dari } \\
\text { suatu konsep }\end{array}$} & Tidak dapat mengidentifikasi contoh dan bukan contoh & 1 \\
\hline & $\begin{array}{l}\text { Dapat mengidentifikasi contoh dan bukan contoh tetapi belum } \\
\text { tepat dan lengkap }\end{array}$ & 2 \\
\hline & $\begin{array}{l}\text { Dapat mengidentifikasi contoh dan bukan contoh dengan tepat } \\
\text { tetapi kurang lengkap }\end{array}$ & 3 \\
\hline & $\begin{array}{l}\text { Dapat mengidentifikasi contoh dan bukan contoh dengan tepat } \\
\text { dan lengkap }\end{array}$ & 4 \\
\hline \multirow{3}{*}{$\begin{array}{l}\text { Menyajikan konsep } \\
\text { dalam bentuk } \\
\text { representasi matematis }\end{array}$} & $\begin{array}{l}\text { Dapat menyajikan sebuah konsep dalam bentuk representasi } \\
\text { matematis (gambar) tetapi tidak tepat }\end{array}$ & 1 \\
\hline & $\begin{array}{l}\text { Dapat menyajikan sebuah konsep dalam bentuk representasi } \\
\text { matematis (gambar) dengan tepat tetapi ukuran pada gambar } \\
\text { salah. }\end{array}$ & 2 \\
\hline & $\begin{array}{l}\text { Dapat menyajikan sebuah konsep dalam bentuk representasi } \\
\text { matematis (gambar) dengan tepat dan ukuran pada gambar benar. }\end{array}$ & 3 \\
\hline \multirow[t]{3}{*}{$\begin{array}{l}\text { Menggunakan prosedur } \\
\text { atau operasi tertentu }\end{array}$} & $\begin{array}{l}\text { Tidak dapat memilih dan menggunakan prosedur atau operasi } \\
\text { dengan tepat }\end{array}$ & 1 \\
\hline & $\begin{array}{l}\text { Dapat memilih dan menggunakan prosedur atau operasi dengan } \\
\text { tepat, tetapi perhitungan salah }\end{array}$ & 2 \\
\hline & $\begin{array}{l}\text { Dapat memilih dan menggunakan prosedur atau operasi dengan } \\
\text { tepat, dan perhitungan benar }\end{array}$ & 3 \\
\hline \multirow{4}{*}{$\begin{array}{l}\text { Mengaplikasikan konsep } \\
\text { secara algoritma dalam } \\
\text { pemecahan masalah }\end{array}$} & $\begin{array}{l}\text { Tidak dapat mengaplikasikan rumus sesuai prosedur dalam } \\
\text { pemecahan masalah }\end{array}$ & 1 \\
\hline & $\begin{array}{l}\text { Dapat mengaplikasikan rumus sesuai prosedur dalam pemecahan } \\
\text { masalah tetapi perhitungan banyak salah. }\end{array}$ & 2 \\
\hline & $\begin{array}{l}\text { Dapat mengaplikasikan rumus sesuai prosedur dalam pemecahan } \\
\text { masalah tetapi perhitungan belum tepat }\end{array}$ & 3 \\
\hline & $\begin{array}{l}\text { Dapat mengaplikasikan rumus sesuai prosedur dalam pemecahan } \\
\text { masalah dengan tepat }\end{array}$ & 4 \\
\hline
\end{tabular}

Dalam proses kualifikasi kemampuan pemahaman konsep matematis, peneliti mengelompokkan hasil jawaban peserta didik pada setiap indikator berdasarkan gender, selanjutnya dicari persentase hasil tes setiap indikator dengan membagi jumlah skor peserta didik dengan skor maksimal dikali jumlah peserta didik dan dikali $100 \%$. Persentase hasil tes yang diperoleh disajikan dalam bentuk diagram batang dan dikualifikasikan berdasarkan Tabel 2 (adaptasi dari Arikunto,2009)

Tabel 2. Kualifikasi Kemampuan Pemahaman Konsep Matematis

\begin{tabular}{|c|c|}
\hline Persentase (\%) & Kualifikasi \\
\hline $81-100$ & Sangat Baik \\
\hline $61-80,99$ & Baik \\
\hline $41-60,99$ & Cukup \\
\hline $21-40,99$ & Rendah \\
\hline $0-20,99$ & Sangat Rendah \\
\hline
\end{tabular}




\section{HASIL DAN DISKUSI}

Hasil penelitian disajikan pada diagram batang yang terdiri dari indikator kemampuan pemahaman konsep matematis dan hasil tes dikelompokkan berdasarkan gender dapat dilihat pada gambar 1. Gambar 1 menunjukkan bahwa pada indikator 1 tentang menyatakan ulang konsep yang telah dipelajari, kemampuan pemahaman konsep peserta didik perempuan sangat baik dengan capaian 90\% dan peserta didik laki-laki juga sangat baik dengan capaian 89\%. Pada indikator 2 yaitu mengidentifikasi contoh dan bukan contoh dari suatu konsep, kemampuan pemahaman konsep matematis peserta didik perempuan baik dengan capaian $77 \%$ sedangkan peserta didik laki-laki cukup dengan capaian $48 \%$.

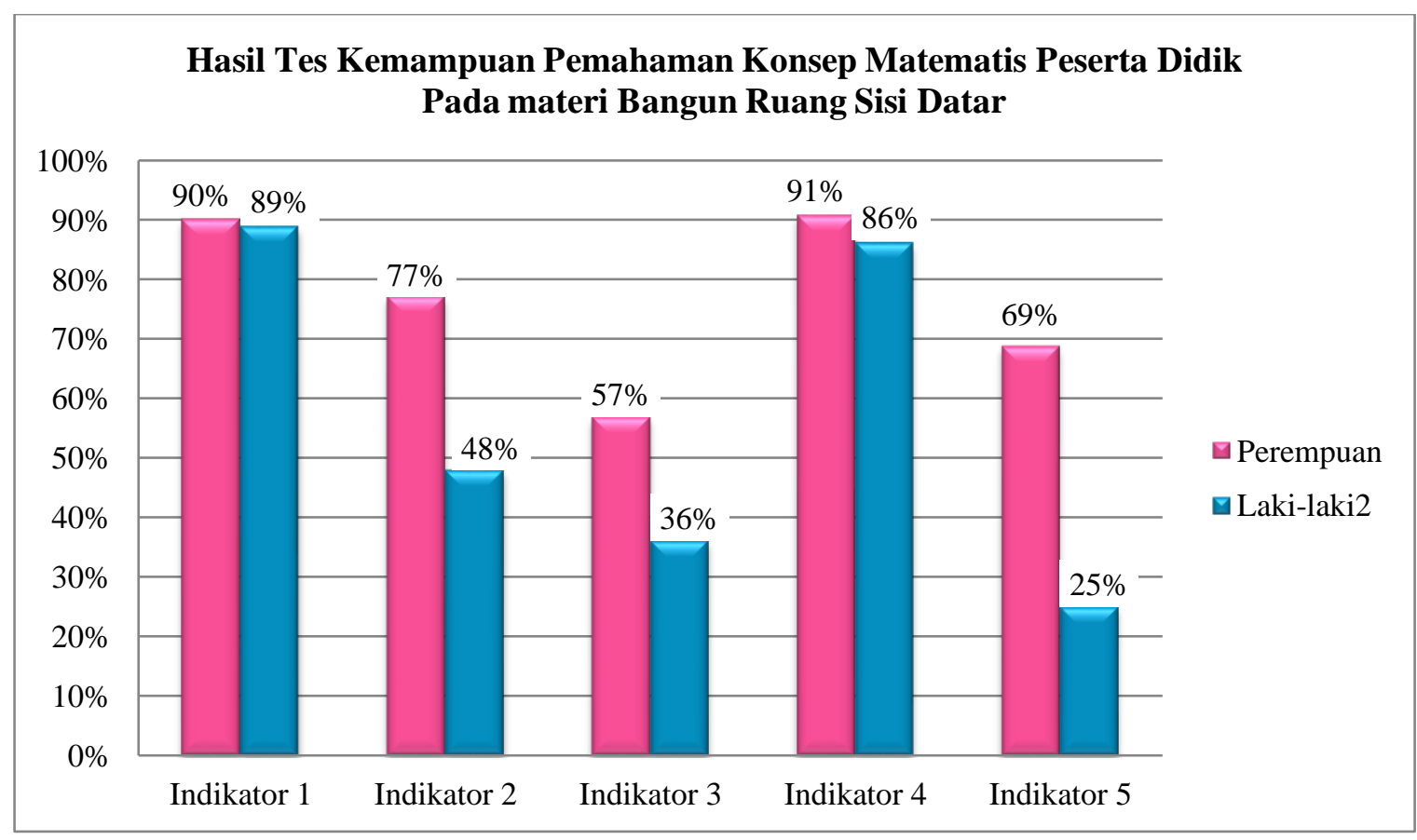

Gambar 1. Diagram Persentase Hasil Tes Kemampuan Pemahaman Konsep Matematis Peserta Didik

Pada indikator 3 yaitu menyajikan konsep dalam bentuk representasi matematis, kemampuan pemahaman konsep matematis peserta didik perempuan cukup dengan capaian 57\% sedangkan peserta didik laki-laki rendah dengan capaian 36\%. Pada indikator 4 yaitu menggunakan prosedur atau operasi, kemampuan pemahaman konsep peserta didik perempuan sangat baik dengan capaian 91\% dan peserta didik laki-laki juga sangat baik dengan capaian 86\%. Pada indikator 5 yaitu mengaplikasikan konsep secara algoritma dalam pemecahan masalah, kemampuan pemahaman konsep matematis peserta didik perempuan baik dengan capaian $69 \%$ sedangkan peserta didik lakilaki rendah dengan capaian $25 \%$.

Dari semua indikator kemampuan pemahaman konsep matematis yang diukur, peserta didik perempuan lemah dalam menyajikan konsep dalam bentuk representasi matematis sedangkan laki-laki lemah dalam mengaplikasikan konsep secara algoritma dalam pemecahan masalah. Secara keseluruhan indikator, rata-rata kemampuan pemahaman konsep matematis peserta didik perempuan 
adalah 76,76 sedangkan peserta didik laki-laki 56,81. Hal ini menunjukkan bahwa peserta didik perempuan memiliki kemampuan pemahaman konsep matematis lebih baik dari laki-laki pada materi bangun ruang sisi datar. Penjabaran dari tiap indikator kemampuan pemahaman konsep peserta didik kelas IX Dang Merdu SMPN 1 Pekanbaru sebagai berikut.

\section{Indikator Menyatakan Ulang Konsep yang Telah Dipelajari}

Indikator ini terkandung pada soal nomor 1 dengan indikator soalnya peserta didik mampu menyatakan ulang konsep mengenai pengertian kubus, balok, prisma dan limas dengan menggunakan bahasa sendiri sehingga peserta didik dapat membedakan yang mana balok, kubus, prisma dan limas dari pengertiannya. Pada indikator ini, kemampuan pemahaman konsep matematis peserta didik perempuan dan laki-laki sangat baik. Peserta didik telah mampu menyatakan ulang konsep bangun ruang sisi datar dengan menuliskan kembali pengertian kubus, balok, limas dan prisma namun terdapat peserta didik yang tidak lengkap dalam menyampaikan konsep sehingga antar konsep sulit dibedakan. Berikut contoh jawaban peserta didik dalam menyatakan ulang pengertian kubus, balok, prisma dan limas.

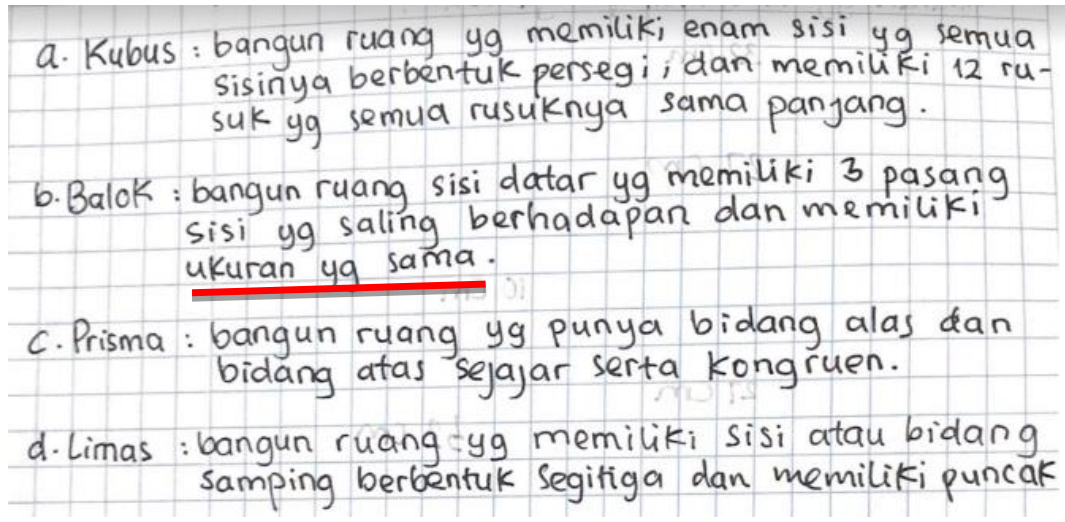

Gambar 2. Jawaban Peserta Didik Perempuan

Gambar 2 menunjukkan bahwa peserta didik perempuan dapat menuliskan ulang pengertian kubus, prisma dan limas menggunakan bahasa sendiri dengan tepat namun belum tepat pada pengertian balok. Peserta didik menuliskan pengertian balok yaitu bangun ruang sisi datar memiliki 3 pasang sisi yang saling berhadapan dan memiliki ukuran yang sama, dimana pengertian balok ini dapat pula merupakan pengertian kubus. Setelah dilakukan wawancara terhadap peserta didik tersebut, peserta didik dapat membedakan yang mana kubus dan yang mana balok. Peserta didik menyadari bahwa pengertian yang ia tulis masih belum lengkap sehingga untuk membedakan kubus dan balok harusnya jawaban peserta didik dilengkapi dengan balok yaitu bangun ruang sisi datar yang memiliki 3 pasang sisi yang saling berhadapan berbentuk persegi atau persegi panjang dan paling tidak satu pasang diantaranya berukuran berbeda. 


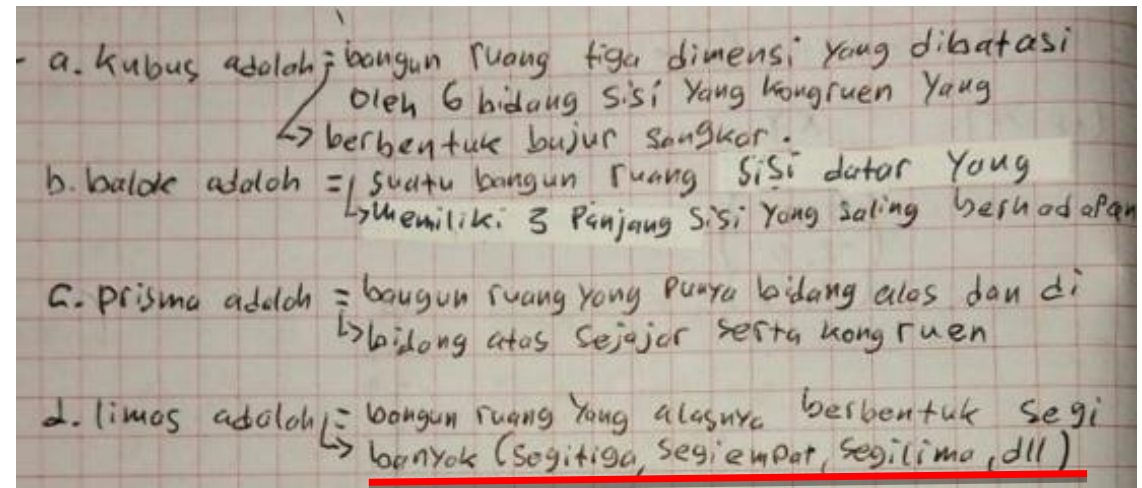

Gambar 3. Jawaban Peserta Didik Laki-laki

Gambar 3 menunjukkan bahwa peserta didik laki-laki dapat menuliskan ulang pengertian kubus dan limas dengan tepat, namun belum tepat untuk pengertian balok dan limas. Pengertian balok dan limas yang dibuat peserta didik masih luas sehingga belum cukup membatasi pengertian balok dan limas. Pada pengertian balok, peserta didik menyatakan bahwa balok merupakan suatu bangun ruang sisi datar yang memiliki 3 panjang sisi yang saling berhadapan, setelah ditanyakan kembali maksud peserta didik adalah balok merupakan suatu bangun ruang sisi datar yang memiliki 3 sisi yang saling berhadapan yang ukurannya sama besar. Pengertian yang disampaikan peserta didik laki-laki sama maksudnya dengan yang disampaikan peserta didik perempuan pada gambar 2. Pengertian limas yang ditulis peserta didik laki-laki masih luas cakupannya sehingga belum menggambarkan konsep limas. Seharusnya jawaban peserta didik dilengkapi dengan sisi tegaknya berbentuk segitiga yang bertemu pada satu titik puncak. Setelah ditanyakan kembali mengenai pengertian limas tersebut kenapa tidak lengkap, peserta didik menjawab lupa sehingga dapat disimpulkan sebagian peserta didik hanya menghapal konsep bukan memahaminya. Secara keseluruhan jawaban peserta didik perempuan lebih panjang dan lengkap dibandingkan laki-laki. Hal ini dikarenakan peserta didik perempuan mempunyai kemampuan verbal yang lebih baik dibandingkan peserta didik laki-laki (Nafi'an, 2011)

\section{Indikator Mengidentifikasi Contoh dan Bukan Contoh dari Suatu Konsep}

Indikator ini terletak pada soal nomor 2 yang indikator soalnya, peserta didik mampu menentukan yang termasuk jaring-jaring suatu kubus atau bukan. Berikut soal nomor 2.

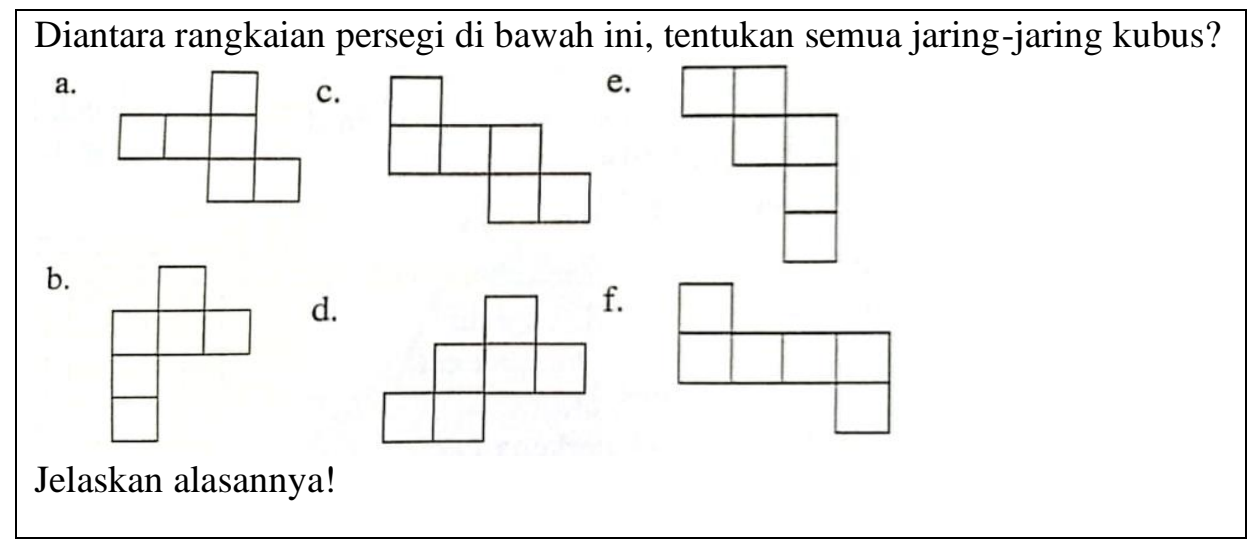

Gambar 4. Soal Nomor 2

Pada indikator ini, kemampuan pemahaman konsep matematis peserta didik perempuan baik 
dan kemampuan peserta didik laki-laki cukup. Dari tujuh gambar jaring-jaring dan bukan jaring-jaring kubus, rata-rata peserta didik perempuan dapat menentukan 3 jaring-jaring kubus yang benar dari 4 jaring-jaring kubus dan rata-rata peserta didik laki-laki hanya dapat menentukan 1 jaring-jaring kubus yang benar. Berikut contoh jawaban peserta didik dalam mengidentifikasi contoh dan bukan contoh dari suatu konsep.

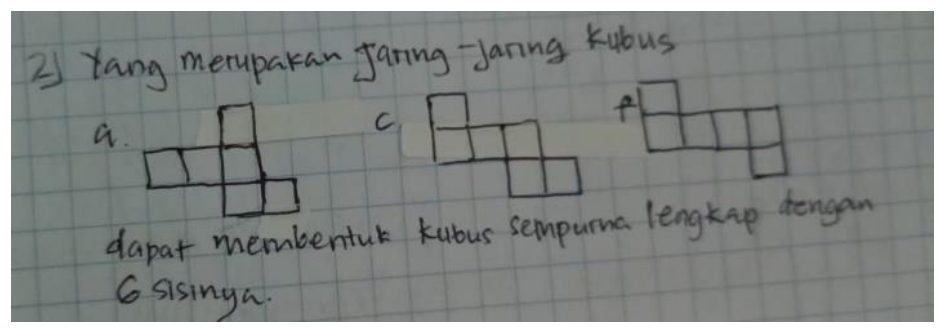

Gambar 5. Jawaban Peserta Didik Perempuan

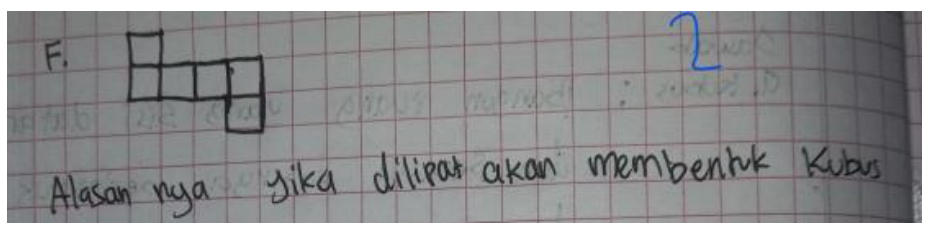

Gambar 6. Jawaban Peserta Didik Laki-laki

Gambar 5 menunjukkan bahwa peserta didik perempuan dapat menentukan 3 jaring-jaring kubus yang benar sedangkan gambar 6 peserta didik laki-laki hanya dapat menentukan 1 jaring-jaring kubus yang benar. Setelah dilakukan wawancara kepada peserta didik perempuan, peserta didik tersebut menyadari kurang teliti dalam menentukan jaring-jaring kubus dan menyatakan bahwa gambar d juga merupakan jaring-jaring kubus, sedangkan yang bukan merupakan jaring-jaring kubus adalah gambar $b$ dan e karena apabila dibentuk ada dua sisi yang saling berhimpit sehingga tidak membentuk kubus. Peserta didik laki-laki juga menyampaikan bahwa tidak teliti menentukan gambar yang merupakan jaring-jaring kubus atau bukan. Peserta didik kurang teliti dalam melihat model jaring-jaring suatu kubus, sehingga terdapat model yang terlewatkan dan jaring-jaring tersebut dapat membentuk bangun ruang kubus (Yuliawati, 2017).

\section{Indikator Menyajikan Konsep dalam Bentuk Representasi Matematis}

Indikator ini terletak pada soal nomor 3 dengan indikator soal peserta didik dapat menyajikan konsep yaitu prisma trapesium sama kaki ke dalam bentuk gambar yang dilengkapi dengan ukurannya. Berikut soal nomor 3.

Sebuah prisma memiliki tinggi $32 \mathrm{~cm}$ dan alas yang berbentuk trapesium sama kaki dengan panjang kaki trapesium $10 \mathrm{~cm}$, panjang garis sejajar alas adalah $15 \mathrm{~cm}$ dan $27 \mathrm{~cm}$.

a. Buatlah gambar prisma tersebut yang dilengkapi ukuran yang diketahui pada gambar!

b. Tuliskan nama prisma yang terbentuk!

\section{Gambar 7. Soal Nomor 3}

Pada indikator ini, kemampuan pemahaman konsep matematis peserta didik perempuan cukup sedangkan kemampuan laki-laki rendah. Berikut contoh jawaban peserta didik dalam menyajikan 
konsep dalam bentuk representasi matematis.
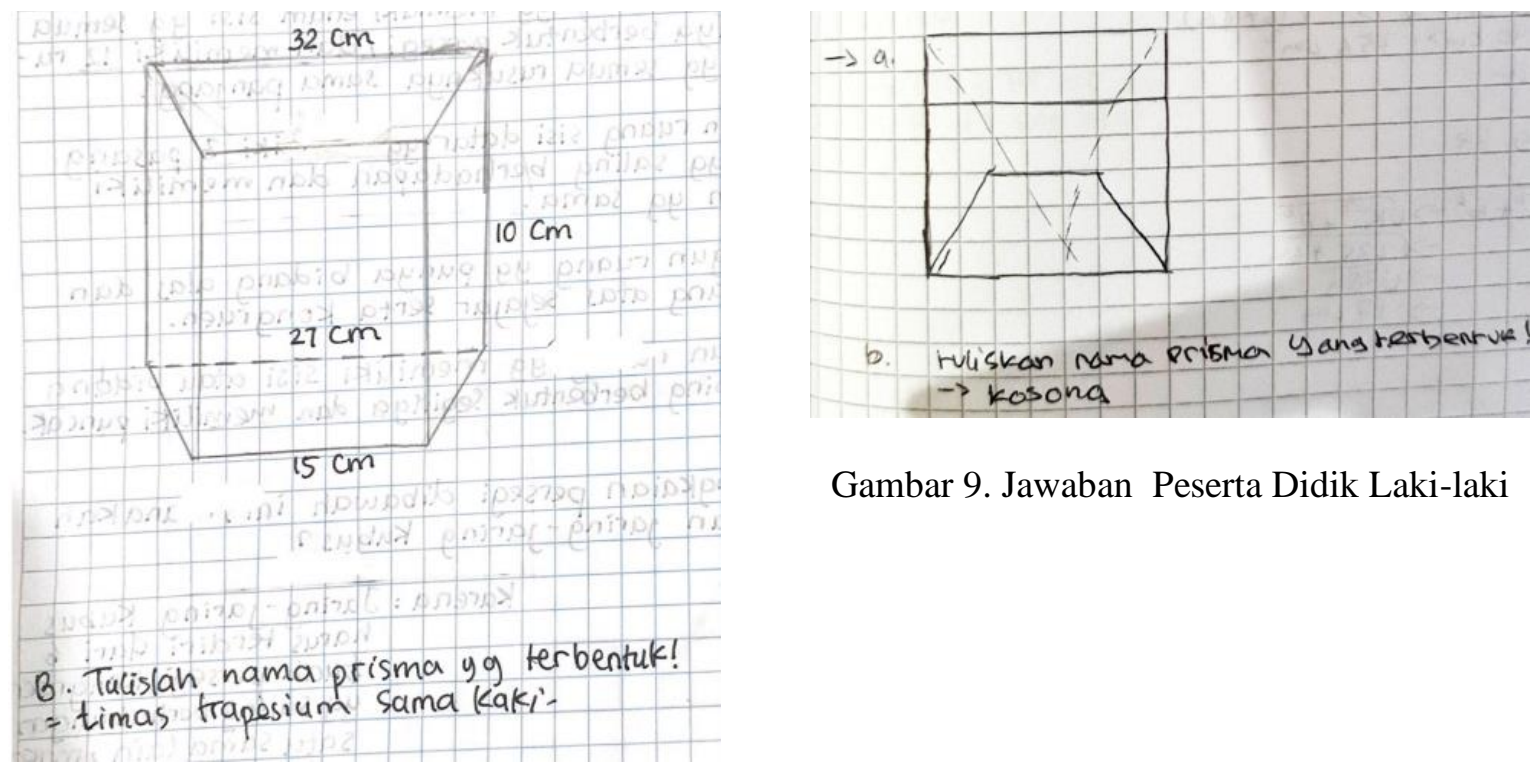

Gambar 9. Jawaban Peserta Didik Laki-laki

Gambar 8. Jawaban Peserta Didik Perempuan

Gambar 8 menunjukkan bahwa peserta didik perempuan telah dapat menggambarkan suatu prisma traspesium dengan rapi namun belum tepat dalam menentukan ukuran yang diketahui pada gambar. Peserta didik perempuan juga tidak dapat menuliskan nama prisma yang terbentuk dengan tepat padahal sudah terdapat pada soal. Hasil wawancara menunjukkan bahwa peserta didik dapat menentukan ukuran yang diketahui pada gambar dan menyebutkan nama prisma yang terbentuk dengan benar. Peserta didik perempuan keliru dalam menentukan ukuran pada gambar dan tidak teliti dalam menuliskan nama bangun ruang sisi datar yang digambar.

Sedangkan pada gambar 9 menunjukkan peserta didik laki-laki yang tidak dapat menggambarkan prisma trapesium sama kaki sehingga tidak dapat dapat menuliskan kembali nama bangun ruang tersebut. Hasil wawancara menunjukkan bahwa peserta didik tidak tahu tentang prisma trapesium sama kaki hanya mengetahui prisma saja. Ketika ditanya mengenai pengertian prisma, peserta didik tersebut dapat menjawabnya sehingga dapat disimpulkan peserta didik hanya menghapal tanpa memaknai konsep prisma. Pada indikator menyajikan konsep dalam bentuk representasi matematis, kemampuan peserta didik lebih baik dan gambar yang dihasilkan rapi dibandingkan dengan laki-laki. Sejalan dengan pendapat Wijaya et al., (2016) yang menyatakan bahwa peserta didik perempuan lebih menerapkan langkah yang berurutan dan sistematis, tulisan yang jelas, rapi, sebagian besar tidak terdapat coret.an pada jawaban karena memperhatikan estetika.

\section{Indikator Menggunakan Prosedur atau Operasi Tertentu}

Indikator ini terletak pada soal nomor 4. Peserta didik dituntut menggunakan rumus volume limas untuk mencari tinggi limas, rumus pythagoras untuk mecari tinggi sisi tegak limas dan rumus luas permukaan limas. 
Perhatikan limas, T. ABCD dengan alas berbentuk segi empat berikut!

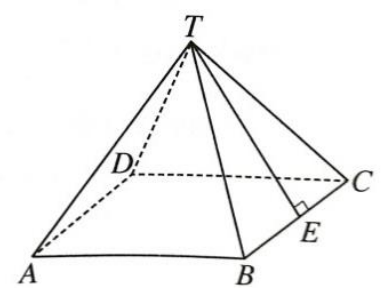

Jika volume limas $\mathrm{T}$. ABCD adalah $1280 \mathrm{~cm}^{3}$, dan panjang rusuk $\mathrm{AB}$ adalah $16 \mathrm{~cm}$, hitunglah:

a. Tinggi limas T. ABCD

b. Panjang TE

c. Luas permukaan T.ABCD

Gambar 10. Soal Nomor 4

Pada indikator menggunakan prosedur atau operasi tertentu, kemampuan pemahaman konsep matematis peserta didik perempuan dan laki-laki sangat baik. Hampir semua peserta didik perempuan maupun laki-laki dapat menggunakan prosedur suatu konsep terentu, namun terdapat peserta didik baik perempuan maupun laki-laki yang keliru dalam menentukan tinggi limas dalam menerapkan luas permukaan limas. Berikut contoh jawaban peserta didik yang keliru dalam menentukan tinggi limas dalam menerapkan luas permukaan limas.

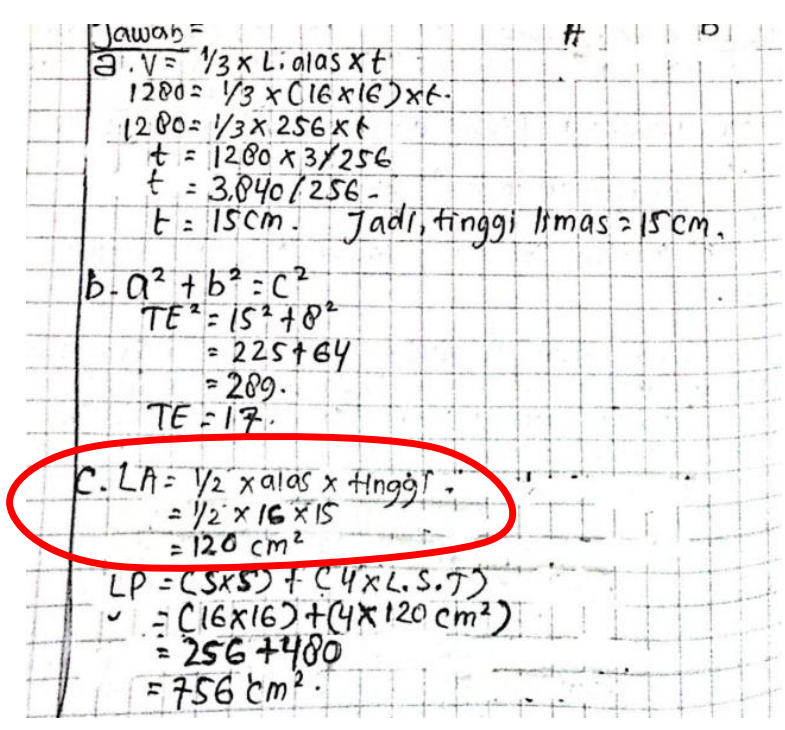

Gambar 11. Jawaban Peserta Didik Perempuan

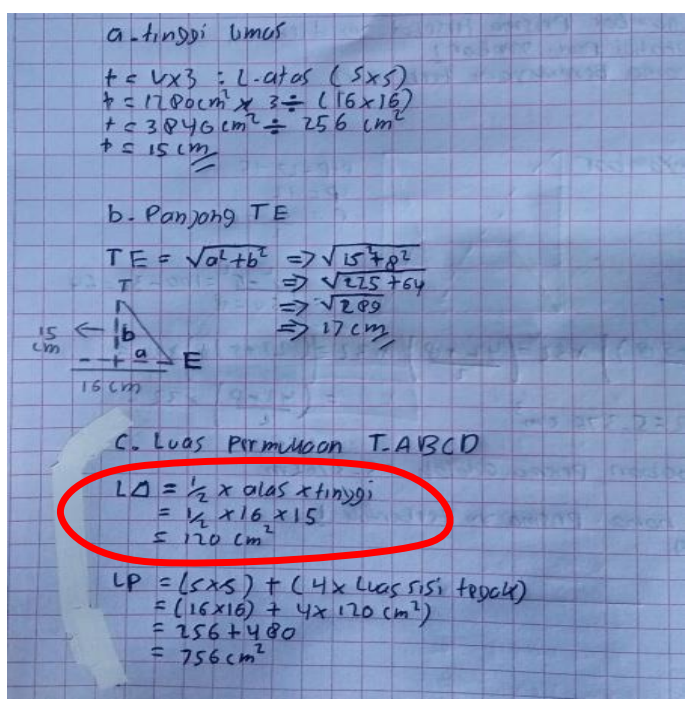

Gambar 12. Jawaban Peserta Didik Laki-laki

Gambar 7 dan gambar 8 terlihat bahwa peserta didik baik perempuan maupun laki-laki tepat dalam menentukan tinggi limas dengan menggunakan rumus volume limas yaitu $\frac{1}{3} \times$ luas alas $\times$ tinggi dan menentukan panjang TE yaitu tinggi sisi tegak limas yang berbentuk segitiga menggunakan rumus Pythagoras. Namun, dalam menentukan luas sisi tegak yang berguna untuk menentukan luas permukaan limas, peserta didik keliru dalam menentukan tingginya, peserta didik menggunakan tinggi limas dan bukan tinggi segitiga yaitu panjang TE, sehingga luas permukaan limas menjadi salah. Sejalan dengan penelitian Sumadiasa, (2014) bahwa peserta didik sering keliru atau tidak cermat dalam menentukan tinggi sisi tegak pada suatu limas sehingga salah dalam 
menentukan voume dan luas permukaan limas.

\section{Indikator Mengaplikasikan Konsep secara Algoritma dalam Pemecahan Masalah}

Indiikator ini terletak pada soal nomor 5 dengan indikator soalnya peserta didik dapat mengaplikasikan konsep keliling balok untuk memperoleh panjang kawat dalam membentuk kerangka akuarium sehingga dapat menentukan biaya yang dibutuhkan untuk pembuatan rangka akuarium tersebut berdasarkan langkah-langkah yang benar. Berikut soal nomor 5 .

Pedagang ikan mas koki akan memproduksi sebuah kerangka akuarium dengan bahan aluminium. Kerangka yang dibuat berbentuk balok, berukuran $1,5 \mathrm{~m} \times 60 \mathrm{~cm} \times 50 \mathrm{~cm}$. Tentukan biaya yang dibutuhkan untuk memproduksi kerangka akuarium jika harga aluminium per meter adalah Rp75.000,00.

\section{Gambar.13 Soal Nomor 5}

Pada indikator ini, kemampuan pemahaman konsep matematis peserita didik perempuan baik, sedangkan kemampuan laki-laki rendah. Semua peserta didik laki-laki salah dalam menggunakan konsep keliling balok. Berikut contoh jawaban peserta didik yang keliru dapat mengaplikasikan konsep jumlah panjang rusuk balok dalam membentuk kerangka akuarium.

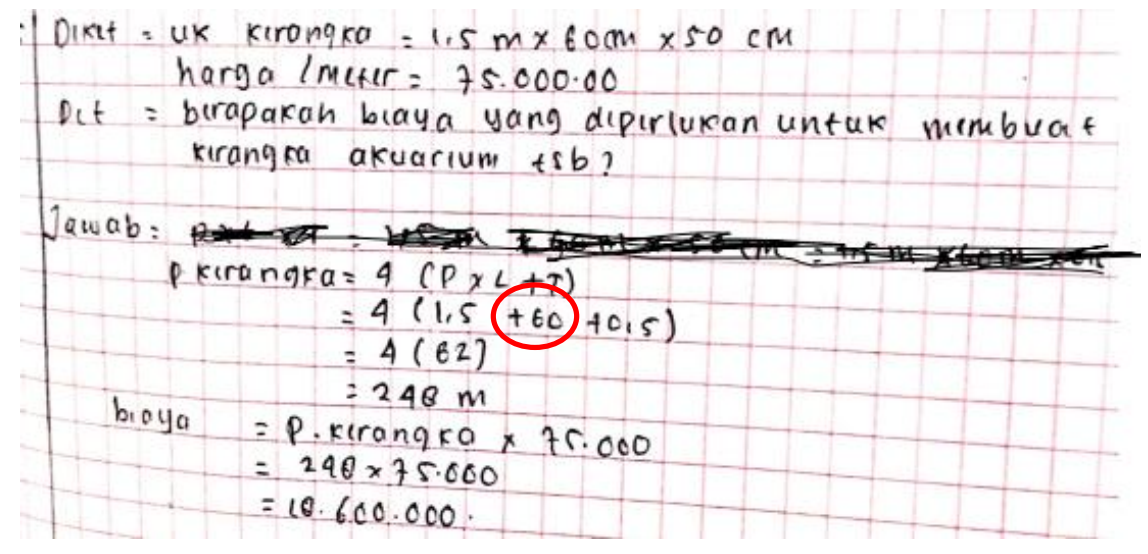

Gambar 14. Peserta Didik Perempuan

Gambar 14 menunjukkan bahwa peserta didik perempuan telah dapat mengaplikasikan konsep keliling balok dalam mencari panjang kerangka yang dibutuhkan yaitu $4(p+l+t)$. Namun peserta didik didik keliru dalam memahami soal yang diberikan. Diketahui bahwa kerangka akuarium berbentuk balok dengan ukuran $1,5 \mathrm{~m} \times 60 \mathrm{~cm} \times 50 \mathrm{~cm}$, namun peserta didik tidak menyamakan satuan pada ukuran terlebih dahulu sehingga menyebabkan salah pada hasil perhitungan. Hasil wawancara menunjukkan bahwa peserta didik paham konsep namun kurang teliti dalam mengubah satuan. 


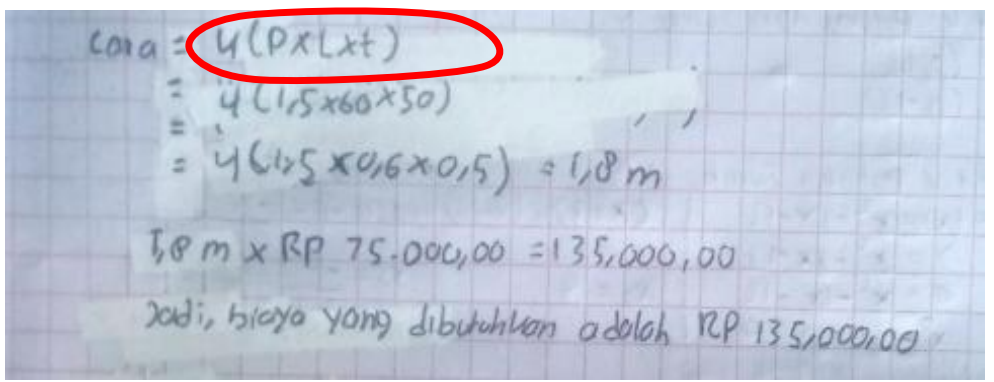

Gambar 15. Jawaban Peserta Didik Laki-laki

Gambar 15 memperlihatkan bahwa peserta didik laki-laki tidak memahami soal sehingga tidak dapat mengaplikasikan konsep keliling balok dalam mencari panjang kerangka yang dibutuhkan. Dari wawancara diperoleh bahwa peserta didik tidak paham terhadap soal yang disajikan dan menyatakan bahwa yang dicari pada soal adalah volume balok. Jika peserta didik tidak memahami soal, maka peserta didik akan salah ketika menerapkan suatu konsep. Hal ini didukung oleh Prihatini et al., (2019) bahwa peserta didik belum paham terhadap soal cerita yang disajikan, sehingga peserta didik tidak dapat menentukan langkah penyelesaiannya yang benar dan terdapat pula kesalahan menerapkan konsep walaupun perhitungannya benar.

\section{KESIMPULAN}

Berdasarkan hasil analisis kemampuan pemahaman konsep matematis ditinjau dari gender, diperoleh bahwa peserta didik perempuan lebih baik daripada laki-laki. Kemampuan pemahaman peserta didik perempuan lebih baik dari laki-laki pada indikator menyatakan ulang konsep yang telah dipelajari, dengan peserta didik perempuan dapat menyatakan pengertian kubus, prisma dan limas sedangkan peserta didik laki-laki dapat menyatakan pengertian kubus dan prisma. Kemampuan pemahaman peserta didik perempuan lebih baik daripada laki-laki untuk indikator mengidentifikasi contoh dan bukan contoh dari suatu konsep dimana peserta didik perempuan lebih lengkap dalam menentukan jaring-jaring kubus dibandingkan laki-laki. Kemampuan pemahaman peserta didik perempuan juga lebih baik daripada laki-laki untuk indikator menyajikan konsep dalam bentuk representasi matematis, menggunakan prosedur atau operasi tertentu serta mengaplikasikan konsep secara algoritma dalam pemecahan masalah.

\section{UCAPAN TERIMA KASIH}

Terima kasih kepada seluruh pihak yang telah berpartisipasi dalam penelitian ini, meliputi guru matematika SMPN 1 Pekanbaru, peserta didik dan dosen yang telah memberikan bimbingan dalam penyusunan artikel. 
Analisis Kemampuan Pemahaman Konsep Matematis Peserta Didik pada Materi Bangun Ruang Sisi Datar Ditinjau dari Gender, Mukhlisatul Humaira Syaifar, Maimunah, Yenita Roza

\section{REFERENSI}

Abdussakir, A. (2012). Pembelajaran Geometri Sesuai Teori Van Hiele. Madrasah, 2(1). https://doi.org/10.18860/jt.v2i1.1832

Achor, E. E. (2010). Sex Differentials in Students' Achievement and Interest in Geometry Using Games and Simulations Technique. Necatibey Faculty of Education Electronic Journal of Science and Mathematics Education Vol. 4, 4(1), 1-10. https://doi.org/10.17522/nefefmed.57480

Badraeni, N., Pamungkas, R. A., Hidayat, W., Rohaeti, E. E., \& Wijaya, T. T. (2020). Analisis Kesulitan Siswa Berdasarkan Kemampuan Pemahaman Matematik Dalam Mengerjakan Soal Pada Materi Bangun Ruang Sisi Datar. Jurnal Cendekia : Jurnal Pendidikan Matematika, 4(1), 247-253. https://doi.org/10.31004/cendekia.v4i1.195

Bayar, S. (2018). Gender, Interest and School Type as Predictors of Academic Achievement in Trigonometry among Secondary School Students in Kano State, Nigeria. ATBU Journal Of Science, Technology And Education, . 6(4), 260-269.

Halimatusadiah, A. M. A. (2017). Pengaruh Pendekatan Kontekstual Berstrategi REACT terhadap Kemampuan Pemahaman Matematis dan Motivasi Belajar Siswa Sekolah Dasar. Mimbar Sekolah Dasar, 4(3), 203. https://doi.org/10.17509/mimbar-sd.v4i3.7766

Handayani, Y., \& Aini, I. N. (2019). Analisis kemampuan pemahaman konsep matematis siswa pada materi peluang. Prosiding Seminar Nasional Matematika dan PendidikanMatematika Sesiomadika 2019, 575-581.

Hendriana, H., Rohaeti, E. E., \& Sumarmo, U. (2017). Hard Skills dan Soft Skills Matematik Siswa. Bandung: Refika Aditama

Hernaeny, U., Marliani, N., \& Marlina, L. (2021). Analisis Kemampuan Pemahaman Konsep Matematika Pada Materi Bangun Ruang Sisi Datar. PROSIDING SEMINAR NASIONAL PENELITIAN DAN PENGABDIAN 2021, "Penelitian dan Pengabdian Inovatif pada Masa Pandemi Covid-19," 1(1), 604-611.

Kartika, Y. (2018). Analisis kemampuan pemahaman konsep matematis peserta didik kelas vii smp pada materi bentuk aljabar. Jurnal Pendidikan Tambusai, 2(2), 777-785.

Khasanah, M., Utami, R. E., \& Rasiman, R. (2020). Analisis Kemampuan Pemahaman Konsep Matematis Siswa SMA Berdasarkan Gender. Imajiner: Jurnal Matematika dan Pendidikan Matematika, 2(5), 347-354. https://doi.org/10.26877/imajiner.v2i5.6517

Kurniasi, E. R. (2016). Profil Pemahaman Matematis Mahasiswa Pendidikan Matematika Ditinjau Dari Jenis Kelamin. Jurnal Prima, V(Ii), 1-7.

Mulyani, A., Indah, E. K. N., \& Satria, A. P. (2018). Analisis Kemampuan Pemahaman Matematis Siswa Smp Pada Materi Bentuk Aljabar. Mosharafa: Jurnal Pendidikan Matematika, 7(2), 251262. https://doi.org/10.31980/mosharafa.v7i2.24

MZ, Z. A. (2013). Perspektif Gender Dalam Pembelajaran Matematika. Marwah: Jurnal Perempuan, Agama dan Jender, 12(1), 15. https://doi.org/10.24014/marwah.v12i1.511 
Nafi'an, M. I. (2011). P - 53 Kemampuan Siswa Dalam Menyelesaikan Soal Cerita. Makalah dipresentasikan dalam Seminar Nasional Matematika dan Pendidikan Matematika dengan tema "Matematika dan Pendidikan Karakter dalam Pembelajaran" pada tanggal 3 Desember 2011 di Jurusan Pendidikan Matematika FMIPA UNY, 978-979.

Penelitian, J. H., Kepustakaan, K., \& Pendidikan, B. (2021). Jurnal Kependidikan: 7(3), 699-707.

Prihatini, S. A., Susilo, D. A., \& Hariyani, S. (2019). Analisis kesalahan siswa dalam menyelesaikan soal cerita spltv berdasarkan tahapan newman. Suska Journal of Mathematics Education, 2(2010), 364-373.

Sumadiasa, I. G. (2014). Analisis Kesalahan Siswa Kelas VIII SMP Negeri 5 Dolo dalam Menyelesaikan Soal Luas Permukaan dan Volume Limas. Jurnal Elektronik Pendidikan Matematika Tadulako, 01(2), 184-207.

Susilowati, J. P. A. (2016). Profil Penalaran Siswa SMP dalam Pemecahan Masalah Matematika Ditinjau dari Perbedaan Gender. Jurnal Review Pembelajaran Matematika, 1(2), 132-148. https://doi.org/10.15642/jrpm.2016.1.2.132-148

Wijaya, H. P. I., Sujadi, I., \& Riadi. (2016). Kemampuan Komunikasi Matematis Siswa Sesuai Dengan Gender Dalam Pemecahan Masalah Pada Materi Balok Dan Kubus (Studi Kasus Pada Siswa Smp Kelas Viii Smp Islam Al-Azhar 29 Semarang). Jurnal Elektronik Pembelajaran Matematika, 4(9), 778-788. http://jurnal.fkip.uns.ac.id

Yani, C. F., Maimunah, M., Roza, Y., Murni, A., \& Daim, Z. (2019). Analisis Kemampuan Pemahaman Matematis Siswa pada Materi Bangun Ruang Sisi Lengkung. Mosharafa: Jurnal Pendidikan Matematika, 8(2), 203-214. https://doi.org/10.31980/mosharafa.v8i2.481

Yulianty, N. (2019). Kemampuan Pemahaman Konsep Matematika Siswa Dengan Pendekatan Pembelajaran Matematika Realistik. Jurnal Pendidikan Matematika Raflesia, 4(1), 60-65. https://doi.org/10.33449/jpmr.v4i1.7530

Yuliawati, E. (2017). Proses Berpikir Kritis Siswa Sekolah Dasar dalam Menemukan Jumlah JaringJaring Bangun Ruang Kubus. Jurnal Universitas Muhammadiyah Sidoarjo. 